\title{
MISTAKE OF LAW - CURRENT STATUS AND PERSPECTIVES
}

A mistake of law in present day criminal law in the world is one of the most interesting legal institutes. Its significance comes from the fact that as a wide-spread institute of criminal law it is in the process of comprehensive transformation equally in both, continental and common law system. Some of the most prominent continental law system institutes proceeded from the traditional mistake of law meaning ignorantia iuris nocet or ignorantia iuris neminem excusat to the excusable mistake of law. In these systems the mistake of law presents an excuse from the convict's responsibility if the mistake of law is non-excusable. In opposite cases, it may present a reason for a lower sentence from its regular value. On the other hand, mainly common law system countries kept firmly to the traditional meaning of the mistake of law institute. In most of these systems, the mistake of law is attached to its traditional phrase: ignorantia iuris nocet or ingnorantia iuris neminem excusat. It means that mistake of law has no effect to a convict's responsibility if he/she objects to the mistake of law. However, even though both systems choose their approaches to the mistake of law problem in the world, it is quite obvious that both systems are not so convinced in decisions they adopted in their systems. Many prominent criminal law theorists in the world try to find out in which way this institute will go in future. This paper is a part of that complex debate.

Keywords: mistake of law, continental, common law, criminal law, system

\section{INTRODUCTION}

Mistake of law presents one of the oldest criminal law institutes in both continental and common law systems. Before long, both systems shared the same meaning of the institute. That traditional meaning of the mistake of law institute was widely known as a Roman law expression ignorantia iuris nocet or ignorantia iuris neminem excusat. The ordinary meaning of this expression is that whoever objects in a criminal procedure that he/she did not know the law, which is breached is actually responsible, because the mistake of law objection does not have excusable meaning. In a very limited number of cases, the mistake of law

\footnotetext{
* LL.M MSc MBA, University of Banja Luka Law School. Email: dragan_pauunovic@yahoo.com.
} 
objection used to be only a reason for mitigating a punishment form. Reasons behind this approach were acceptable and reasonable, especially for that time. Actually, for centuries the number of laws and different prohibition norms in almost all systems in the world were rather small. Their understanding was mainly attributable to two reasons. First, the limited number of prohibition acts, and second, the fact that these prohibitions usually overlapped with the same traditional religious norms, understandable to everyone at that time. No one was in a position to say that he/she did not know that killing somebody is illegal or that stealing anyone's property is allowed. There was a universal consensus in the whole world at the time that the acts, like killing, stealing, betraying or similar ones were forbidden. As it was said before, these prohibitions were mainly listed in religious books, including the Bible, but not only in them. Modern societies adopted different norms that govern ordinary people's lives in those societies. In the very beginning, they coincided with similar religious orders. However, over the time, these civil regulations grew up and became more and more numerous. At certain moments, the number of different prohibitions and their complexity became so complicated that ordinary people were not able to understand and to respect them. For a short period of time, the situation in which somebody had difficulties to understand and to follow certain rules moved to almost complete inability to understand and to pursue them. The second half of the XX century and first two decades of XXI century were very important moments in the world development, when the number of formal norms increased enormously and reached a number never met before in human history. For example, Larkin $(2013$, p. 1) stated that "the result in recent decades has been the "overcriminalization" of the law, with thousands of criminal offenses in federal statutes and hundreds of thousands in federal regulations. No person could possibly expect to know them all or even to know all of those that may apply to his/her daily activities." So, the author (Larkin, 2013, p. 1) continues that "there are more than 4,500 federal crimes and potentially more than 300,000 relevant federal implementing regulations. No one could know them all - not a judge, not a lawyer, and certainly not an average citizen untrained in the law." In such circumstances, it becomes almost clear that the traditional mistake of law approach in a criminal law is not applicable any more. It was very difficult to expect from somebody to know all these regulations or their core or wider description or punishment for that specific criminalization. Because of that, contemporary criminal law theorists and practitioners initiated consideration of another approach to the issue of the mistake of law. That new approach was based on the need for recognition of the fact that it could not be expected from the modern age man to know all regulations and to follow them. The outcome of such concerns was the widespread professional opinion that the mistake of law should be an excuse only in some limited situations and under very strict conditions. Some criminal law systems recognized that need even during the first half of the XX centuries, like China in 1920, Denmark in 1930, Switzerland in 1937, Argentine in 1951, and Japan in 1961 (Стевановић, 1989, p. 72). However, the first systematic approach to the recognition of the mistake of law as an excusable institute occurred in Germany during seventies of the XX century (Neuman, 1996, p. 207). Later on, many other countries adopted the same legal doctrine, including France, Italy, Poland and some other EU countries. In addition, some other non-EU 
countries such as Serbia, Montenegro, North Macedonia, and Republic of Srpska also adopted the same legal doctrine (Бабић-Марковић, 2007, 265). Since that moment, the trend of recognition of the mistake of law as an excusable legal institute has been spreading in many countries of the continental legal system, as well as in some countries of the common law system. However, even though such trend was obvious, it was not a global and unanimously accepted one. Still many criminal law systems in the world remained stuck to the traditional non-excusable mistake of law institute, as it is the case with the USA, Great Britain and others, and within some continental systems, like it is the case with the Russian Federation, Ukraine and many others. Interestingly, these systems look for solutions to soften the current traditional conservative approach regarding the mistake of law institute, while criminal law systems that accepted the excusable mistake of law institute set many additional restrictions upon this institute in terms of strict implementation rules or limited number of cases where the institute was implemented. For instance, Arzt (1986, p. 731) noticed that “...on a practical level, recognizing that mistake of law may excuse has not led to breakdown of law and order in Germany." Arzt (1986, p. 731) continued with the explanation for such an outcome with the explanation that "the defense is so complicated that a disproportionate number of those who benefit are either lawyers or defendants who are well counseled by lawyers." On the other hand, the USA Model Penal Code and many state laws accepted certain modifications of the traditional mistake of law non-excusable institute. Simmons (2003, p. 181) stated that "figuring out which mistakes and which cases of ignorance will result in nonliability is just a question of "logical relevance": Does the mistake or ignorance negate the required mens rea or not?" It is a sign of decades long streaming of some American criminal law theorists and practitioners who tried to emphasize the unsustainability of the current situation with the mistake of law institute as a non-excusable approach in the USA. Among them, Larkin Jr. takes a significant place. Larkin $\operatorname{Jr}(2013$, p. 77-78) emphasized the opinion of certain scholars who "believe that it (mistake of law institute) should be re-examined and rejected or modified". They believe, regardless of what was true at common law, it no longer is credible to claim that everyone knows the law, particularly since " $[t]$ he tight moral consensus that once supported the criminal law has obviously disappeared." So, what is the current position of both systems and which way both systems will go regarding the mistake of law institute is one of the most interesting and significant legal dilemmas in the modern criminal law.

\section{TRADITIONAL MISTAKE OF LAW APPROACH}

Traditional approach in the civil criminal law system is based on the Roman law maxima ignorantia iuris nocet or ignorantia iuris neminem excusat. Similarly, the common law systems define the institute of the mistake of law as non-excusable in the XVIII century, William Blackstone Commentaries (Blackstone, 1753). As Hall (1957, p. 15) noticed, "the Roman theory - that the law is 'definite and knowable' - seems to have been interpreted quite literally." Consequently, Blackstone (1753, p. 27) noted that "every person of discretion[...] may[...] know it", so ignorance is non-excusable. Following Blackstone's approach, Hall (1957, p. 19) found that "to permit an individual to plead successfully that he had a different 
opinion or interpretation of the law would contradict the above postulates of legal order." Actually, the rationale for the traditional mistake of law institute that comes from the Roman expressions ignorantia iuris nocet and ignorantia iuris neminem excusat has two aspects. The first one is "that the principle of legality implies the doctrine of ignorantia iuris, while the second one is "that the doctrine is necessary to the maintenance of the objective morality of the community" (Hall, 1957, p. 23). This approach has remained dominant theory in modern criminal law for centuries. Based on these elements, the knowledge of illegality has become a crucial and unavoidable part of the mens rea that is needed for one's culpability. Deeply incorporated inside the mens rea institute, the ignorance of the law has not had any particular relevance for one's culpability. The theory has also prevailed in normative regulations of almost all criminal law systems up to the $\mathrm{XX}$ century. These systems accepted the strict criminal liability principle as the primary one. The commonly accepted exception to the principle was in the area of punishment. Under certain circumstances, the one who has committed a crime and objected to his/ her responsibility because of the mistake of law could be punished less than those who were fully aware of the crime they had committed. Both, the continental and the common law system, have this principle incorporated in their criminal laws. The USA criminal law system has kept its primary strict liability principles up to now. So has Great Britain. But, not only common law system countries have remained committed to the traditional ignorantia iuris nocet principle. Many continental criminal law system countries also have remained committed to the same principle. It is the case with the Russian Federation, Ukraine, and many other countries. The way these countries implement the principle varies but the doctrine has remained the same. Holmes Jr. (2011, p. 45) is clear that "ignorance of the law is no excuse for breaking it." Arzt (1986, p. 712) quoted Fletcher who criticized this approach as an "instrumental approach [...] that is typical, however, for initial phases of doctrinal development in the field of mistake of law." Verseveld (2012, p. 10) emphasizes an "almost mystical power held by the maxim (ignorantia iuris nocet) over the judicial imagination." Even though some contemporary theorists suggest certain corrections within strict principles, many theorists "suggest that a defense of reasonable mistake of law should be accepted in the case of malum prohibitum offences but not in the case of malum in se offenses..." (Simmons, 2008, p. 8). This tendency was materialized in the first legal codification on federal level in the USA, known as Model Penal Code (1985, p. 26-28). The codification adopted light softening of the strict rule regarding the mistake of law in a certain way that will be explained in the next chapter. Despite new tendencies, the strict liability rule remained and preserved its primary place in the US criminal law system which also meant the non-excusable mistake of law institute. Similarly, Great Britain also based its mistake of the law approach on Blackstone Commentaries (Blackstone, 1753). That meant the domination of the ignorantia legis non excusat principle in the English criminal law (Verseveld, 2012, p.18). Nevertheless, the English law is much more rigorous in implementing the non-excusable mistake of law institute. Two explanations play crucial role for such approach. First, as Smith (Verseveld, 2012, p.18) noted it is about the fact that "English Courts lack the power to declare statutes unconstitutional, like American courts can under article 2.04(3)(b) Model Penal Code", while the second one lies in "... 
the fact that the English system applies without much difficulty the doctrine of strict liability to a whole range of regulatory offences in which mistake of law is most likely to occur." Consequently, the mistake of law institute is irrelevant for one's culpability in the English law. In accordance to that, the Criminal law Draft from 1989 clearly stated that "... ignorance or mistake as to a matter of law does not affect liability to conviction for offence except (a) where so provided, or (b) where it negatives the fault element of the offence" (van Verseveld, 2012, p.18). In a different way but following the same principle, continental criminal law systems that remained adhered to the ignorantia iuris nocet and ignorantia iuris neminem excusat expressions from the Roman law, define the mistake of law institute in their normative documents as a non-excusable institute. The Russian Federation and Ukraine are typical examples of the continental criminal law system that followed the ignorance of the law approach without consequences to one's culpability. The mistake of law institute does not make formal consequences as it is the case in the German criminal law, for instance. A defendant in Russia cannot raise the mistake of law institute in order to prove his/her innocence. The mistake of law institute in the Russian Criminal Code is defined as a "wrong perception" of some conduct or act legality or illegality (Петрович, 2008, p. 102). However, the mistake of law institute has been indirectly included in some crime acts in the Russian Criminal Code. This is the case with the crime acts related to the labor protection (Article 143 Russian Criminal Code), pyrotechnics' handling and protection (Article 218 Russian Criminal Code) and fire protection (Article 219 Russian Criminal Code) (Петрович, 2008, p. 102). Also, as Veresha (2016, p. 8021) stated, "mistake of law in Ukrainian criminal law has no criminal-legal value." Similar to the Russian Federation, the mistake of law institute has been involved in the criminal law system in Ukraine in some ways and does affect one's culpability. This is the case with Article 212 of the Criminal Code of Ukraine and Articles 52-53 of the Tax Code of Ukraine that will be explained below (Veresha, 2016, p. 8021).

In sum, a traditional mistake of law approach, regardless of certain countries and their criminal codes could basically only mitigate the punishment without significant impact on somebody's culpability. However, in the second half of the XX century, this approach started to change. The end of the XX century was a turning point for considering the institute of the mistake of law in a different way than it was the case before.

\section{CONTEMPORARY MISTAKE OF LAW APPROACH}

As a matter of fact, the second half of the XX century was just a time of turning point. In essence, the real reason behind this new trend was in the overcriminalization that hit the up-to-date world. There is no specific definition of the notion of "overcriminalization", but it could be presented easier. Larkin Jr. firstly mentioned this phrase and gave its extra explanation (Larkin, 2013, p. 2). He recalled the fact that the rule against the mistake of law as a defense made sense during the development of the English common law, the ancestor of our common law, hundreds of years ago (Larkin, 2013, p. 2). But, the author (Larkin, 2013, p. 2) further noted that it is not the case anymore given that only in the USA "there are more than 4,500 federal crimes and potentially more than 300,000 relevant 
federal implementation regulations. In a similar vein, Vuković (Вуковић, 2014, p. 464) talks about "hypertrophy of legal norms that [...] alienate legal norm from its roots - a social and moral norm". As a result of that, Vuković (Вуковић, 2014, p. 464) concluded that global society came in a situation that "it is legally forbidden something that an average person does not see as socially destructive, socially unallowed or morally inadmissible". Besides moral and social arguments, some authors questioned justification aspect of the institute of the ignorance of the law. For instance, Kumuralingam (1995, p. 429) stated it was "suffice to say that the rule's historical origin is uncertain, its rationale for existence questionable, and its application in criminal law without certainty." Consequently, as we stated above, criminal law of some continental law systems have started considering ignorance of law as a defense under certain and defined circumstances, while on the other hand, common law criminal systems have been keeping to the principle that the mistake of law is no defense. In the civil law system, Germany and France accepted an approach under which ignorance of law is a defense in certain situations.

The mistake of law was introduced as a defense in Germany with the historical court decision in the case Bundesgerichtshof from March 18, 1952 (Verseveld, 2012, p. 26). Before that court decision, the German Criminal Law from 1871 had not recognized mistake of law as a defense or as an excuse (Verseveld, 2012, p. 26). Since the Bundesgerichtshof decision, Vesterveld (2012, p. 28) stated that in the case of ignorance of law, "the perpetrator is fully aware of the factual circumstances of his behavior, but he erroneously believes his behavior to be lawful." Even though this court decision made historical breakthrough in the civil law criminal system, almost twenty-three years had passed before this principle was incorporated in the German Criminal Code (StGB) in 1975 (Verseveld, 2012, p. 26). Since then, Article 17 of the German Criminal Code clearly defines that "if the perpetrator, when committing the act, lacks the insight into his wrong-doing, he is not criminally liable if this mistake was unavoidable. In the case; this mistake was avoidable, the punishment can be mitigated according to Article 49, sec. 1." (Neumann, 1996, p. 208). So, knowledge of unlawfulness is not an element of mens rea, as it used to be the case before that and as it is the case in many other civil and common law systems, but the element of criminal liability, which is the part of, the so called, Schuldtheorie in the German criminal law theory (Neumann, 1996, p. 208). Today, the German Criminal Code recognizes direct and indirect mistake of law. The direct mistake means that "the defendant is completely ignorant of the norm in question", while the indirect mistake means that "the defendant knows the norm in question and its legal scope, but erroneously believes there is a justification for his behavior in violation of this norm" (Verseveld, 2012, p. 28-29). Also, it is necessary to mention that, in accordance with the German criminal law theory, "the knowledge of the moral wrongfulness of the act" is not enough to establish the mistake of law defense (Neumann, 1996, p. 209). It is also the case with "the social harm" approach for which there is a wider consensus that is closer to the criminal law request regarding the excusable mistake of law institute than the "moral wrongdoing" but still not enough (Verseveld, 2012, p. 38, Neumann, 1996, p. 210). What is suffice to establish the mistake of law defense is "the knowledge that the act is in opposition to the binding substantive value order of the law and is, thus, legally prohibited" (Neumann, 1996, p. 211). Thereby, the mistake of law 
institute adopted in the German criminal law theory and practice have been an example followed by many continental law systems, mainly in Europe.

The French mistake of law institute model presents a combination of both, the German civil law and the Anglo-American common law system. What comes from the AngloAmerican common law system is its loyalty to the Roman law principle or to the basic rule known as ignorantia iuris nocet or ignorantia iuris neminem excusat (Verseveld, 2012, p. 48). What comes from the German civil law system is the recognition of the mistake of law defense under very strict conditions. This is the unique approach of the French Criminal Code. Article 122-123 of the Penal Code explains the mistake of law as follows: "A person is not criminally liable who establishes that he believed he could legitimately perform the action because of a mistake of law that he was not in a position to avoid" (French Penal Code, 2005). Similarly, Elliot states "A person is not criminally responsible who can justify having believed he or she could legitimately accomplish the act in question, as a result of an unavoidable mistake of law" (Elliot, 2000, p. 37). Therefore, the French Penal Code recognizes only the unavoidable mistake of law as a ground for excluding criminal liability. Desports and Le Gunehec (2007, p. 622-689) define three main conditions that should be fulfilled in order to exclude one's criminal liability as a result of the ignorance of law. These are: "first, the defendant must have made a mistake of law; second, the mistake (or ignorance) must have been unavoidable; and third, the defendant was certain about the lawfulness of his act..." (Desports and Le Gunehec, 2007, p. 622-689, Verseveld, 2012, p. 50). The French approach is considered unique mostly due to the fact that it combines two major approaches coming from two different criminal law systems.

Other civil law systems, basically in Europe, usually follow the German criminal law approach regarding the issue of the mistake of law. This means that the mistake of law as a separate institute excludes the defendant's liability instead of excluding his/her mens $r e a$ as it is the case in the Anglo-American common law systems. This is the case in Italy (Kirsch, 1999), Austria, Spain, Norway, Poland, San Marino, France, Japan (Veresha, 2016, p. 8018), and many other countries in Europe as well.

\section{PERSPECTIVES}

Nevertheless, in principle it cannot be concluded that the overall criminal law systems are globally divided in those that adopted the avoidable mistake of law institute and those which did not do so. The current trends and perspectives are more complex and they cannot be simplified. As a matter of fact, even though two approaches regarding the institute are evident, they are not strict and both have certain deviations from their basic principles. In the case of the common law system, the deviation lies in the fact that some state codes and the federal Model Penal Code accepted the mistake of law institute under certain conditions. On the other hand, certain civil law systems that are based on the ignorantia iuris nocet or ignorantia iuris neminem excusat principle, have also adopted the excusable mistake of law institute in very specific cases. On the contrary, civil law systems that adopted the unavoidable mistake of law institute as an excuse have registered a very restrictive implementation practice. 
Actually, even though principally the most of common law systems remained stuck to the ignorantia iuris nocet or ignorantia iuris neminem excusat principle, some of them adopted certain normative solutions that accepted the excusable mistake of law institute under specific references. The South African Criminal Code accepted the mistake of law institute as an excuse under conditions similar to those in civil law systems (Kumuralingam, 1995, p. 430). On the other hand, the Model Penal Code has anticipated the excusable mistake of law in very limited situations. The Model Penal Code Article 2.04 emphasized that "ignorance or mistake as to a matter of fact or law is defense if (a) the ignorance or mistake negatives the purpose, knowledge, belief, recklessness or negligence required to establish a material element of the offence" (Fletcher, 1998, p. 155). Similarly, Article 2.04 anticipates that "a belief that conduct does not legally constitute an offence is a defense to prosecution for that offence based upon such conduct when: (a) the statute or other enactment defining the offence is not known to the actor and has not been published or otherwise reasonably made available prior to the conduct alleged or (b) he acts in reasonable reliance upon an official statement of the law, afterward determined to invalid or erroneous, contained in (i) a statute or other enactment; (ii) a judicial decision, opinion or judgment; (iii) an administrative order or grant of permission; (iv) an official interpretation of the public officer of body charged by law with responsibility of the interpretation, administration or enforcement of the law defining the offence" (Verseveld, 2012, p. 12). Besides that, some state courts in certain decisions also open the room for the excusable mistake of law to enter the strict liability system in the USA state court practice. For instance, in the case Cheek v. U.S. (1991), the Supreme Court explained the meaning of the "willfulness" element in some tax cases. It said that the "willfulness" element "requires the Government to prove that the law imposed a duty on the defendant, that the defendant knew of this duty, and that he voluntarily and intentionally violated that duty" (Cheek v. U.S., 1991). In regard of such decision, Verseveld (2012, p. 14) concluded that "this means that a good faith mistake, whether reasonable or not, will negate the element of willfulness." This deviation practice from the basic rule the ignorantia iuris nocet or ignorantia iuris neminem excusat is not the exception only in the common law systems, but in the civil law systems that adopted the same rule, as well. For instance, in Ukraine, the mistake of law "has no criminal-legal value" (Versesha, 2016, p. 8021). It is the case even in regard to Article 212 of the Ukrainian Criminal Code that anticipates tax evasion as a criminal act for tax-payers who evade the tax. However, Articles 52 and 53 of the Ukrainian Tax Code stipulate that "relevant bodies provide tax-payers with free consultations on the practical implementations of specific norms of tax legislation" (Versesha, 2016, p. 8021). So, in regard of that, the Ukrainian criminal practice stands the position that "tax-payers who acted on the advice of the tax consultant, which was put on paper, cannot be prosecuted" (Versesha, 2016, p. 8021-8022). Similar to Ukraine, some theorists in the Russian Federation, like Yurievich (Юрьевич, 2014, p. 133) recommends the editing of Article 141 of the Russian Federation Criminal Code in a way the mistake of law to have positive influence on one's liability, which means to be an excusable institute. From the following examples we can see that most of criminal law systems that are loyal to the traditional ignorantia iuris nocet or ignorantia iuris neminem excusat principles have been looking for certain legal solutions to address the general need 
for a different approach in the era of the "overcriminalization" (Larkin, 2013, p. 1) that puts many people in an unfair position to be liable for disobeying laws and regulations they have never heard of. Interestingly, on the other hand, criminal systems that adopted the excusable mistake of law institute have registered different practice that would be expected in regard of that criminal law institute. Actually, the tendency in these systems' practice is completely different. For example, Arzt (1986, p. 731) underlined that "...on a practical level, recognizing that mistake of law may excuse has not led to a breakdown of law and order in Germany." Moreover, the author (Arzt, 1986, p. 731) concluded that "the defense is so complicated that a disproportionate number of those who benefit are either lawyers or defendants who are well counseled by lawyers." Similarly, Babic and Markovic (Бабић-Марковић, 2007, p. 266) also state that domestic practice in Republic of Srpska and other former Yugoslav countries in regard of the excusable mistake of law institute is also very restrictive. It looks like that most of these systems are very cautious in its implementation, most probably with the idea not to let this new criminal law institute make radical changes in terms of defendant's culpability. In our opinion, this is a positive approach to the excusable mistake of law institute because these systems want to see real effects from its implementation on a practical level prior to their final attitude regarding the institute's future.

\section{CONCLUDING REMARKS}

The mistake of law as a criminal law institute has been based on traditional principles ignorantia iuris nocet or ignorantia iuris neminem excusat for centuries. Even though some theorists question the origin of the principle, the position of the principle has been undisputable up to recent days. The mistake of law institute was established in the Roman law, as a main source of the civil law systems, but also in the Blackstone's Commentaries, as a main source of the common law system. Since the second half of the XX century, the situation has changed, primarily as a result of the huge increase of numbers of different laws and regulations. Certain theorists referred to that phenomenon as to "overcriminalization." Consequently, some criminal law systems adopted the mistake of law as an excusable institute that negates one's liability under certain conditions, thus not only mitigating the punishment, as it was the case with the institute's traditional form and meaning. Germany and many other continental law systems made the breakthrough in recognizing the new status of the institute of the mistake of law in criminal law. Some common law systems did the same but most of them remained loyal to the traditional meaning of the ignorantia iuris nocet or ignorantia iuris neminem excusat principle. However, even though a new trend with the excusable mistake of law institute have been evident, the practice has not followed the same enthusiasm as it was with theorists. Actually, the current practice is very restrictive, mainly because of a very complicated defense concept in regard of the excusable mistake of law. Despite that, many criminal law systems that are stuck to the mistake of law traditional meaning have decided to move toward accepting some forms of the excusable mistake of law under very strict conditions. In such circumstances, it is apparent that the mistake of law perspective will be characterized with two following tendencies: first, 
further softening of the traditional approach with accepting different excusable forms of the concept and second, further restrictive implementation of the excusable mistake of law institute, mainly as a result of the justified vigilance of criminal law practitioners. In our opinion, this cautiousness of criminal law practice is needed and acceptable. Only in that way, new mistakes of law meaning could be properly managed by the court system and the criminal law theory in order to prevent its negative consequences and to bring forth benefit to all in the modern world. 


\section{LIST OF REFERENCES}

Arzt, G. 1986. The Problem of Mistake of Law. BYU Law Review, 3(8), pp. 712-731.

Бабић, М. \& Марковић, И. 2007. Кривично право, општи део. Бања Лука: Правни факултет.

Blackstone, W. 2011. Commentaries on the Laws of England in Four Books. Indianapolis.

Desportes, F. Le Gunehec, F. 2007. Droit pénal général, 14th edn. Economica. Paris.

Elliott, C. 2000. The French law of intent and its influence on the development of international criminal law. Criminal Law Forum. 11, pp. 35-46.

Fletcher, G.P. 1998. Basic Concepts of Criminal Law. Oxford University Press. 3, pp. 155.

French Penal Code 2005.

Hall, J. 1957. Ignorance and mistake in criminal law. Indiana Law Journal. 33(1), pp. 19.

Holmes, O. W. Jr. 2011. The Common Law. Toronto.

Kirsch, A. 1999. France Mistake of law in French criminal law. Amicus Curiae.

Kumaralingam, A. 1995. Mens Rea and Mistake of Law in Criminal Cases: A Lesson from South Africa. UNSW Law Journal. 18:2, pp. 429-430.

Larkin, P.J. Jr. 2013. The Need for a Mistake of Law Defense as a Response to Overcriminalization. Legal Memorandum. 91, pp. 1-78.

Model Penal Code-Official Draft and Explanatory Notes - Complete Text of Mode Penal Code as Adopted at the 1962 Annual Meeting of The American Law Institute at Washington, D.C. May 24, 1962. 1985.

Neumann, U. 1996. Mistake of Law. Israel Law Review. 30, pp. 207-212.

Петрович, Б. А. 2008. Российское уголовное право. Москва.

Simmons, K. W. 2003. Should the Model Penal Code's Mens Rea Provisions Be Amended? Ohio State Journal of Criminal Law. 1:179, pp. 8-181.

Simmons, K. W. 2008. Mistake of Fact or Mistake of Criminal Law? Explaining and Defending the Distinction. Boston University School of Law. 08-32, pp. 8.

Стевановић, М. 1989. Правна заблуда у кривичном праву, Београд.

Veresha, R. 2016. Mistake of Criminal Law and its Influence on the Classification of Crime. International Journal of Environmental \& Science Education. 11:15, pp. 8018-8022.

Verseveld, A. 2012. The Theory of Mistake of Law-Excusing Perpetrators of International Crimes, The Hague.

Вуковић, Н. Одређена питања стварне и правне заблуде у кривичном праву. Зборник радова Правног факултета у Новом Саду. 1/2014, pp. 464. 
Юрьевич, П. А. 2014. Институт ошибки в романо-германском уголовном праве: компаративистский и теоретико-прикладной аспекты, Краснодар.

Cheek v. United States, 498 U.S. 192, 196 (1991). 